\title{
The Effects of Phosphate Concentration on $\mathrm{N}_{2}$ - and $\mathrm{NH}_{4}^{+}$-grown Klebsiella pneumoniae
}

\author{
By F. J. BERGERSEN* \\ Agricultural Research Council Unit of Nitrogen Fixation, \\ University of Sussex, Falmer, Brighton BNI $9 Q J$
}

(Received 27 May 1974)

INTRODUCTION

It is widely believed by agricultural scientists that $\mathrm{N}_{2}$-fixing leguminous plants have a higher requirement for inorganic phosphate than plants grown with combined nitrogen. Phosphatic fertilizers may become scarce in the future and it is important to establish the magnitude of the effect, if it exists. Nitrogen-fixing micro-organisms may be used to study the problem. Nitrogen-fixation by blue-green algae in lake waters is proportional to phosphate concentration, and the $\mathrm{C}_{2} \mathrm{H}_{2}$-reduction test for nitrogenase can be used as a sensitive assay for dissolved phosphate (Stewart, Fitzgerald \& Burris, 1970). Dalton \& Postgate (1969) studied phosphate-limited continuous cultures of Azotobacter chroococcum and reported that yields are higher for $\mathrm{NH}_{4}{ }^{+}$-grown than for $\mathrm{N}_{2}$-grown cultures. However, the experiments are complicated by differences in sensitivity to $\mathrm{O}_{2}$ between phosphate-limited and control bacteria.

This communication reports an experiment with the facultative $\mathrm{N}_{2}$-fixing bacterium Klebsiella pneumoniae grown in continuous culture with either $\mathrm{N}_{2}$ or $\mathrm{NH}_{4}{ }^{+}$as the $\mathrm{N}$-source and with a range of limiting inorganic phosphate concentrations.

\section{METHODS}

Continuous cultures of Klebsiella pneumoniae strain M5a I were grown according to the methods described by Baker (I968). The medium contained glucose ( $15 \mathrm{~g} / \mathrm{l}), \mathrm{MgSO}_{4} \cdot 7 \mathrm{H}_{2} \mathrm{O}$ $(0 \cdot 1 \mathrm{~g} / \mathrm{l}), \mathrm{NaMoO}_{4} \cdot 2 \mathrm{H}_{2} \mathrm{O}(8 \mathrm{mg} / \mathrm{l})$ and ferric citrate $(36 \mathrm{mg} / \mathrm{l}), \mathrm{pH} 7 \cdot 0$, autoclaved in 101 reservoir bottles at $\mathrm{I} 22^{\circ} \mathrm{C}$ for $\mathrm{I} \mathrm{hr}$. The phosphate concentrations required were obtained by the addition of sterile I M-potassium phosphate, $\mathrm{pH} 7 \cdot 0$, to culture vessel and reservoirs, which were calibrated for volume.

Preliminary experiments established that the minimum phosphate concentration permitting establishment of a steady state was $0.05 \mathrm{~mm}$, with a dilution rate of $0 \cdot \mathrm{I} \mathrm{h}^{-1}$. Also, with this dilution rate, the cultures became glucose-limited with $0.25 \mathrm{~mm}$-phosphate. The range 0.05 to $0.2 \mathrm{~mm}$-phosphate was therefore used for the experiment. Cultures produced acid rapidly and therefore $\mathrm{pH}$ was controlled at $7 \cdot 0 \pm 0 \cdot 2$ by the automatic addition of I N-KOH. The medium flow was maintained to give a dilution rate of $0.1 \pm 0.005 \mathrm{~h}^{-1}$ with a culture volume of $400 \mathrm{ml}$. The gas phase was $\mathrm{N}_{2}$, supplied at $100 \mathrm{ml} / \mathrm{min}$.

The culture was established at $0.05 \mathrm{~mm}$-phosphate by inoculating with $200 \mathrm{ml}$ of an overnight culture in thioglycollate medium and then grown for 3 days in steady state before observations were commenced. The first series used $\mathrm{N}_{2}$ and then was repeated with medium

* Present address: Division of Plant Industry, Commonwealth Scientific and Industrial Research Organization, Canberra, A.C.T. 26oI, Australia. 
Table I. The effects of growth-limiting phosphate concentration on continuous cultures of Klebsiella pneumoniae M5a I

\begin{tabular}{|c|c|c|c|c|c|c|c|}
\hline N-source & $\begin{array}{l}\text { Phosphate } \\
\text { (mM) }\end{array}$ & $\begin{array}{l}\text { Culture } \\
\text { density* }\end{array}$ & $\begin{array}{c}\text { Cell } \\
\text { yield } \dagger \\
(\mu \mathrm{g} \text { dry } w \mathrm{t} / \mathrm{ml})\end{array}$ & $\begin{array}{c}\text { Cell N } \ddagger \\
(\%)\end{array}$ & $\begin{array}{l}\text { Glucose } \\
\text { utilized } \\
\left(\mathrm{mg} \mathrm{ml}^{-1}\right)\end{array}$ & $Y_{\text {glucose }}$ & $\begin{array}{c}\text { Mol } \mathrm{NH}_{4}{ }^{+} \\
\text {assimi- } \\
\text { lated/mol } \\
\text { glucose } \\
\text { utilized }\end{array}$ \\
\hline $\begin{array}{l}\mathbf{N}_{2} \\
\mathbf{N}_{2} \\
\mathbf{N}_{2} \\
\mathbf{N}_{2}\end{array}$ & $\begin{array}{l}0.05 \\
0.10 \\
0.125 \\
0.20\end{array}$ & $\begin{array}{r}8 \cdot 5 \\
20 \cdot 3 \\
25 \cdot 0 \\
33 \cdot 0\end{array}$ & $\begin{array}{l}66 \pm 6 \\
194 \pm 10 \\
260 \pm 12 \\
375 \pm 6\end{array}$ & $\begin{array}{c}- \\
12 \cdot 2 \pm 1 \cdot 3 \\
I 1 \cdot 0 \pm 0 \cdot 9 \\
12 \cdot 3 \pm 0 \cdot 9\end{array}$ & $\begin{array}{c}2 \cdot 93 \pm 0.02 \\
5 \cdot 0 \pm 0.5 \\
7 \cdot 20 \pm 0.05 \\
12 \cdot 2 \pm 0.3\end{array}$ & $\begin{array}{l}0.023 \\
0.039 \\
0.036 \\
0.031\end{array}$ & $\begin{array}{l}- \\
0.06 \\
0.06 \\
0.05\end{array}$ \\
\hline $\begin{array}{l}\mathrm{NH}_{4}{ }^{+} \\
\mathrm{NH}_{4}^{+} \\
\mathrm{NH}_{4}^{+} \\
\mathrm{NH}_{4}^{+}\end{array}$ & $\begin{array}{l}0.05 \\
0.10 \\
0.125 \\
0.20\end{array}$ & $\begin{array}{r}8 \cdot 0 \\
19 \cdot 3 \\
25 \cdot 5 \\
34 \cdot 8\end{array}$ & $\begin{array}{l}74 \pm 7 \\
215 \pm 8 \\
305 \pm 6 \\
447 \pm 11\end{array}$ & $\begin{array}{r}8 \cdot 6 \pm 0.5 \\
10 \cdot 4 \pm 1 \cdot 3 \\
11 \cdot 0 \pm 1 \cdot 1 \\
11 \cdot 3 \pm 0 \cdot 2\end{array}$ & $\begin{array}{c}3 \cdot 4 \pm 0.1 \\
6.3 \pm 0.2 \S \\
- \\
I 1 \cdot 24 \pm 0.03 \S\end{array}$ & $\begin{array}{c}0.022 \\
0.035 \\
- \\
0.040\end{array}$ & $\begin{array}{c}0.02 \\
0.05 \\
0.06\end{array}$ \\
\hline
\end{tabular}

* Absorbance at $625 \mathrm{~nm}$ in arbitrary scale units.

$\dagger$ Means with standard deviations; duplicate samples with duplicate weighings.

$\ddagger$ Means with standard deviations for total $\mathrm{N}$ of duplicate samples of washed, dried cells analysed in duplicate.

$\S$ Only one medium supernatant analysed in triplicate; all other glucose determinations made in duplicate on duplicate samples.

containing $100 \mu \mathrm{g}$ of $\mathrm{N} / \mathrm{ml}$ as $\left(\mathrm{NH}_{4}\right)_{2} \mathrm{SO}_{4}$, which totally repressed nitrogenase (Tubb \& Postgate, 1973). Eighteen hours after each change in culture conditions, $30 \mathrm{ml}$ samples were withdrawn from the culture vessel at intervals of $6 \mathrm{~h}$. Between these samples, the effluent culture was collected in an ice-cooled flask. If the samples were identical in terms of cell density (absorbance at $625 \mathrm{~nm}$ ), $\mathrm{pH}$ and glucose content, the culture was considered to be in steady state and the samples and effluent were kept for analysis. Cultures were centrifuged at $4{ }^{\circ} \mathrm{C}$, the bacteria washed twice with ice-water and finally resuspended in the initial volume of distilled water. Washed bacteria and culture supernatants were stored at $-10{ }^{\circ} \mathrm{C}$. Some supernatants were preserved with chloroform. Dry weights were obtained by drying $10 \mathrm{ml}$ portions of washed bacteria at $80^{\circ} \mathrm{C}$. Glucose was analysed by the anthrone method (Scott \& Melvin, I953) and nitrogen by Kjeldahl digestion followed by a micro-diffusion step and colorimetric estimation of the $\mathrm{NH}_{4}{ }^{+}$(Chaney \& Marbach, 1962).

\section{RESULTS AND DISCUSSION}

The data obtained are summarized in the Table. Over the range of phosphate concentrations studied, there was a progressive increase in the yield (dry weight) of $\mathrm{NH}_{4}{ }^{+}$-grown $K$. pneumoniae over $\mathrm{N}_{2}$-grown cells, although the absorbances of the cultures at any one phosphate concentration were similar. The cell percentage-nitrogen values did not increase between 0.1 and $0.2 \mathrm{mM}$-phosphate and were not significantly different between $\mathrm{N}_{2}$ - and $\mathrm{NH}_{4}{ }^{+}$-grown cultures.

Nitrogenase action requires ATP which must be regenerated in the cells by phosphorylation of ADP. In a chemostat study of Clostridium pasteurianum, Daesch \& Mortenson (1967) concluded that differences between yields of $\mathrm{NH}_{4}{ }^{+}$and $\mathrm{N}_{2}$-grown cultures could be attributed to substrate being utilized for this purpose, thus depleting that available for synthesis. It might be expected that an effect would be observed with limiting phosphate. If there was a higher rate of ATP use by $\mathrm{N}_{2}$-fixing cultures and if phosphorylation of ADP was limited by phosphate concentration, the differences in yield and/or $\mathrm{N}$-content between cultures grown 
on the two $\mathrm{N}$-sources might be greater with increasing phosphate deficiency. However, for yield the reverse was observed, and the $\mathrm{N}$-content of the cultures was not greatly affected by phosphate concentration. From 0.1 to $0.2 \mathrm{~mm}$-phosphate, the efficiency of glucose utilization ( $\mathrm{Y}_{\text {glucose }}$ ) decreased for $\mathrm{N}_{2}$-grown cultures and increased for $\mathrm{NH}_{4}{ }^{+}$-grown cultures. For both, $Y_{\text {glucose }}$ was very low at $0.05 \mathrm{~mm}$-phosphate.

These results therefore do not support the contention that $\mathrm{N}_{2}$-fixing systems have a higher phosphate requirement than systems utilizing combined $N$. Rather, they indicate that restriction of cellular synthetic processes by phosphate limitation is greater than any restriction of $\mathrm{N}_{2}$-fixation which may occur and that the differences at the higher phosphate concentrations were due to differences in ATP utilization, as described by Daesch \& Mortenson (1967) and Dalton \& Postgate (1969).

The author was on study leave at the Unit of Nitrogen Fixation and thanks the Commonwealth Scientific and Industrial Research Organization, the Royal Society Commonwealth Fund for a travel grant, and the Underwood Fund of the Agricultural Research Council for a grant. Professor J. Chatt and Professor J. R. Postgate are thanked for the hospitality given in the laboratories of the Unit.

\section{REFERENCES}

BAKeR, K. (1968). Low cost continuous culture apparatus. Laboratory Practice 17, 817-824.

Chaney, A. L. \& Marbach, E. P. (1962). Modified reagents for determination of urea and ammonia. Clinical Chemistry 8, 130-132.

Daesch, G. \& Mortenson, L. E. (1967). Sucrose catabolism in Clostridium pasteurianum and its relation to $\mathrm{N}_{2}$ fixation. Journal of Bacteriology 96, 346-351.

Dalton, H. \& Postgate, J. R. (1969). Growth and physiology of Azotobacter chroococcum in continuous culture. Journal of General Microbiology 56, 307-319.

Scott, T. A. \& Melvin, E. H. (1953). Determination of dextran with anthrone. Analytical Chemistry 25, I656-166I.

Stewart, W. D. P., Fitzgerald, G. P. \& Burris, R. H. (1970). Acetylene reduction assay for determination of phosphorus availability in Wisconsin lakes. Proceedings of the National Academy of Sciences of the United States of America, 66, I 104-I I I .

TubB, R. S. \& Postgate, J. R. (1973). Control of nitrogenase synthesis in Klebsiella pneumoniae. Journal of General Microbiology 79, I03-I 17. 